\title{
Pelaksanaan Inisiasi Menyusu Dini (IMD) Pada Ibu Bersalin di Rumah Bersalin Ny. Soegiarti Surabaya.
}

\author{
Yefi Marliandiani dan Katrina Loisa Bernadus \\ Tenaga Pengajar Prodi. D III KebidananUniversitas PGRI Adi Buana Surabaya
}

\begin{abstract}
ABSTRAK
Inisiasi Menyusu Dini (IMD) adalah bayi mulai menyusu sendiri segera setelah lahir. Rendahnya pengetahuan ibu, motivasi ibu dan sikap ibu yang kurang mendukung IMD menjadi faktor dari ibu bersalin terhadap kegagalan IMD. Pelaksanaan IMD dilakukan oleh Bidan yang memfasilitasi dan ibu harus saling mendukung. Penelitian ini bertujuan untuk mengetahui gambaran tentang pelaksanaan IMD pada ibu bersalin.

Desain penelitian digunakan metode Deskriptif Kuantitatif. Populasi dalam penelitian ini adalah seluruh ibu bersalin normal di RB Ny. Soegiarti Surabaya. Sampel sebanyak 30 responden dengan kriteria inklusi yaitu ibu dan bayi yang dilaksanakan IMD. Teknik sampling purposive sampling. Variabel pada penelitian ini adalah Pelaksanaan Inisiasi Menyusu Dini, sedangkan Sub variabelnya adalah posisi bayi, upaya mencegah bayi kedinginan, bayi mencari putting susu, lamanya bayi menyusu. Teknik analisis data menggunakan statistic deskriftif persentase dengan instrument kuesioner.

Hasil penelitian diperoleh bahwa dari 30 responden langkah-langkah pelaksanaan IMD yaitu bayi ditengkurapkan di dada atau perut ibu sebanyak 30 responden (100\%) dilakukan dengan tepat, kulit bayi melekat dengan kulit ibu tanpa dialasi kain 26 responden (87\%) dilakukan dengan tepat, upaya mencegah bayi kedinginan dengan kepala bayi dapat dipakaikan topi dan diselimuti pada daerah punggung bayi 20 responden (67\%) dilakukan tepat, bayi dibiarkan untuk mencari sendiri puting susu ibunya dan bayi tidak dipaksakan ke puting susu 9 responden (30\%), bayi tetap dibiarkan dalam posisi kulitnya bersentuhan dengan kulit ibu sampai proses menyusu pertama selesai atau selama 1-2 jam 14 responden (47\%). Pelaksanaan IMD di RB. Soegiarti kurang maksimal karena masih ada langkah yang kurang tepat.

Pelaksanaan IMD harus lebih ditingkatkan. Diharapkan kepada para bidan agar meningkatkan kemampuan dan pengetahuan tentang IMD dengan mengikuti pelatihan-pelatihan dan seminar-seminar tentang IMD agar pelaksanaan IMD dapat dilaksanakan secara optimal dan terus-menerus.
\end{abstract}

Kata Kunci : Pelaksanaan IMD, Ibu Bersalin

\section{PENDAHULUAN}

Inisiasi Menyusu Dini (IMD) atau early initiation atau permulaan menyusu dini adalah bayi mulai menyusu sendiri segera setelah lahir. Jadi, sebenarnya bayi manusia seperti juga bayi mamalia lain mempunyai kemampuan untuk menyusu sendiri, asalkan dibiarkan kontak kulit bayi dengan kulit ibunya, setidaknya selama satu jam segera setelah lahir. Cara bayi melakukan inisiasi menyusu dini ini dinamakan the breast crawlatau merangkak mencari payudara.(Roesli Utami, 2012).

Inisiasi menyusu dini berperan dalam pencapaian tujuan Millenium Development Goals (MDGs), khususnya pada tujuan keempat, yakni membantu mengurangi angka kematian bayi. Menurut data dari Survei
Demografi dan Kesehatan Indonesia (SDKI) tahun 2007, Angka Kematian Bayi (AKB) di Indonesia pada tahun 2007 sebesar 34/1000 Kelahiran Hidup. Ini artinya setiap hari bayi meninggal dan sekitar 146.000 bayi meninggal sebelum mencapai usia satu tahun. Kematian bayi baru lahir dapat dicegah jika bayi disusui oleh ibunya dalam satu jam pertama setelah kelahirannya.

Berdasarkan data di Badan Pusat Statistik (BPS), Angka Kematian Bayi di Jawa Timur tahun 2005-2011 turun dari 36.65 (tahun 2005) menjadi 29.24 per 1.000 kelahiran hidup (tahun 2011). Angka tersebut masih jauh dari target MDG's tahun 2015 sebesar 23 per 1.000 kelahiran hidup. Penurunan Angka Kematian Bayi mengindikasikan peningkatan derajat kesehatan masyarakat sebagai salah satu 
wujud keberhasilan pembangunan di bidang kesehatan.(Profil Kesehatan Propinsi Jawa Timur, 2011).

Keputusan Menteri Kesehatan Republik Indonesia Nomor 450/MenKes/SK/IV/2004 tentang pemberian Air Susu Ibu (ASI) secara eksklusif pada bayi di Indonesia menyatakan bahwa pemberian ASI secara eksklusif bagi bayi di Indonesia sejak bayi lahir sampai dengan bayi berumur 6 bulan dan dianjurkan dilanjutkan sampai anak berusia 2 tahun dengan pemberian makanan tambahan yang sesuai. Di Indonesia cakupan pemberian ASI Eksklusif pada bayi 0-6 bulan menunjukkan peningkatan dari $61,3 \%$ tahun 2009 menjadi $61,5 \%$ pada tahun 2010. Namun cakupan pemberian ASI Eksklusif pada bayi sampai 6 bulan turun dari $34,3 \%$ pada tahun 2009 menjadi 33,6\% pada tahun 2010. (Pedoman Pekan ASI Sedunia, 2012).

Cakupan Inisiasi Menyusu Dini pada bayi secara nasional masih sangat rendah. Hal ini terlihat pada laporan hasil Riskesdas tahun 2010 hanya 29,3\% bayi yang menyusu kurang dari satu jam setelah persalinan. Menurut Fikawati, Inisiasi Menyusu Dini akan menentukan kesuksesan menyusui selanjutnya, karena ibu yang memberikan ASI dalam satu jam pertama setelah melahirkan mempunyai peluang 2-8 kali lebih besar untuk memberikan ASI eksklusif. (http://pustaka.unpad.ac.id/03/03/2013).

Berdasarkan data di Jawa Timur diketahui bahwa cakupan bayi yang mendapat ASI Eksklusif tahun 2011 sebesar 61,52\%. Cakupan tersebut mengalami peningkatan yang sangat tajam dibandingkan dengan tahun sebelumnya sebesar $31,2 \%$. Hal ini sangat dipengaruhi oleh faktor pemahaman atau Definisi Operasional (DO) yang berubah pada awal tahun 2010. Sampai awal tahun 2010 pemahaman ASI-Eksklusif oleh pelaksana gizi di lapangan adalah murni bayi yang berusia 6 bulan yang hanya mendapat ASI saja. Sedangkan pengertian ASI-Eksklusif menurut Kemenkes maupun $\mathrm{WHO}$, adalah bayi yang berusia 0-6 bulan yang masih diberi ASI saja pada saat didata. Artinya, bila ada bayi yang berumur 0 bulan atau 1 bulan dan seterusnya sampai 5 bulan masih diberi ASI saja, maka pada saat itu diadicatat sebagai bayi 0-6 bulan yang eksklusif, sehingga angkanya jelas jauh lebih tinggi dibanding dengan yang murni 6 bulan eksklusif. (Profil Kesehatan Propinsi Jawa Timur, 2011).
Seorang ibu yang baru melahirkan berharap bisa menyusui bayinya setelah lahir. Inisiasi menyusu dini adalah memberikan kesempatan pada bayi untuk mulai menyusu segera setelah ia dilahirkan. Begitu lahir, bayi tidak dipisahkan tetapi langsung diletakkan di dada ibu. Bayi tidak dimandikan, hanya dikeringkan dengan cara dilap menggunakan kain atau handuk kering (kecuali daerah tangannya), lemak putih yang menutupi sebagian tubuhnya pun masih dibiarkan menempel di tubuh bayi. Semua tindakan yang dilakukan pada bayi (seperti suntikan dan pemberian vitamin) bisa ditunda dahulu setidaknya hingga proses ini selesai (Riksani, 2012).

Keberhasilan atau kegagalan dalam pelaksanaan IMD dipengaruhi oleh beberapa faktor antara lain adalah ibu bersalin menghadapi banyak hambatan untuk melakukan IMD terhadap bayinya, beberapa faktor tersebut diantaranya karena kurangnya dukungan yang diberikan oleh keluarga dan juga dukungan dari tenaga kesehatan serta banyaknya ibu yang belum dibekali pengetahuan yang cukup tentang manfaat dari pelaksanaan IMD. Selain itu keberhasilan program IMD juga sangat dipengaruhi oleh sikap, pengetahuan dan motivasi bidan/dokter penolong persalinan itu sendiri. Kurangnya pengetahuan dari orang tua, pihak medis maupun keengganan untuk melakukannya membuat IMD masih jarang dipraktikkan. (Roesli Utami, 2012).

Berdasarkan studi pendahuluan melalui wawancara terhadap 7 orang ibu bersalin di Rumah Bersalin (R.B.) Ny. Soegiarti surabaya, sebagian besar (5 orang) ibu bersalin tidak dilakukan IMD pada persalinannya, adapun alasan yang disampaikan semuanya mengatakan karena tidak difasilitasi oleh bidan yang menolong persalinan. Sebanyak 2 orang ibu mengatakan bahwa pada persalinannya telah melaksanakan IMD, karena dianjurkan oleh petugas kesehatan.

Menurut Green dalam Notoatmodjo (2010), menyampaikan analisisnya bahwa kesehatan seseorang atau masyarakat dipengaruhi oleh 2 faktor pokok, yakni faktor perilaku (behavior causes) dan faktor diluar perilaku (non behavior causes). Selanjutnya perilaku terbentuk atau ditentukan dari 3 faktor yaitu: pertama, faktor-faktor predisposisi (predisposing factor) yang terwujud dalam pengetahuan, sikap, kepercayaan, keyakinan, 
nilai-nilai dan sebagainya. Kedua faktor-faktor pendukung (enabling factor), yang terwujud dalam lingkungan fisik, tersedia atau tidak tersedianya fasilitas-fasilitas dan saranasarana kesehatan. Ketiga, faktor-faktor pendorong (reinforcing factosr) yang terwujud dalam sikap dan perilaku petugas kesehatan atau petugas yang lain yang merupakan kelompok referensi dari perilaku masyarakat. (Notoatmodjo, 2010)

Berdasarkan latar belakang yang telah diuraikan, maka peneliti tertarik untuk melakukan penelitian dengan judul Pelaksanaan Inisiasi Menyusu Dini (IMD) Pada Ibu Bersalin di R.B. Ny. Soegiarti Surabaya.

\section{Perumusan Masalah}

Inisiasi menyusu dini (IMD) dapat meningkatkan pemberian ASI secara ekslusif pada bayi sehingga dapat menekan angka kematian bayi usia 0-28 hari hingga $22 \%$. Berdasarkan studi pendahuluan melalui wawancara terhadap 7 orang ibu bersalin di Rumah Bersalin (R.B.) Ny. Soegiarti surabaya, sebagian besar (5 orang) ibu bersalin tidak dilakukan IMD pada persalinannya, adapun alasan yang disampaikan semuanya mengatakan karena tidak difasilitasi oleh bidan yang menolong persalinan.

Berdasarkan latar belakang dapat disimpulkan rumusan masalahnya yaitu "Bagaimanakah pelaksanaan IMD di RB. Ny. Soegiarti Surabaya?"

\section{METODE PENELITIAN}

\section{A. Desain Penelitian}

Desain penelitian yang digunakan pada penelitian ini adalah deskriftif. Yaitu dilakukan untuk mendeskripsikan atau menggambarkan suatu fenomena yang terjadi di masyarakat (Notoatmodjo, 2010) yang dalam hal ini adalah menggambarkan pelaksanaan inisiasi menyusu dini (IMD) di RB. Ny. Soegiarti Surabaya.

Dalam penelitian ini akan digambarkan langkah-langkah pelaksanaan IMD pada ibu bersalin normal di RB Ny. Soegiarti Surabaya.

\section{B. Waktu dan Tempat Penelitian}

Waktu penelitian dilakukan pada bulan Oktober - Desember 2013, sedangkan tempat penelitian dilakukan di Rumah Bersalin Ny. Soegiarti

Surabaya

\section{Kerangka Kerja Penelitian}

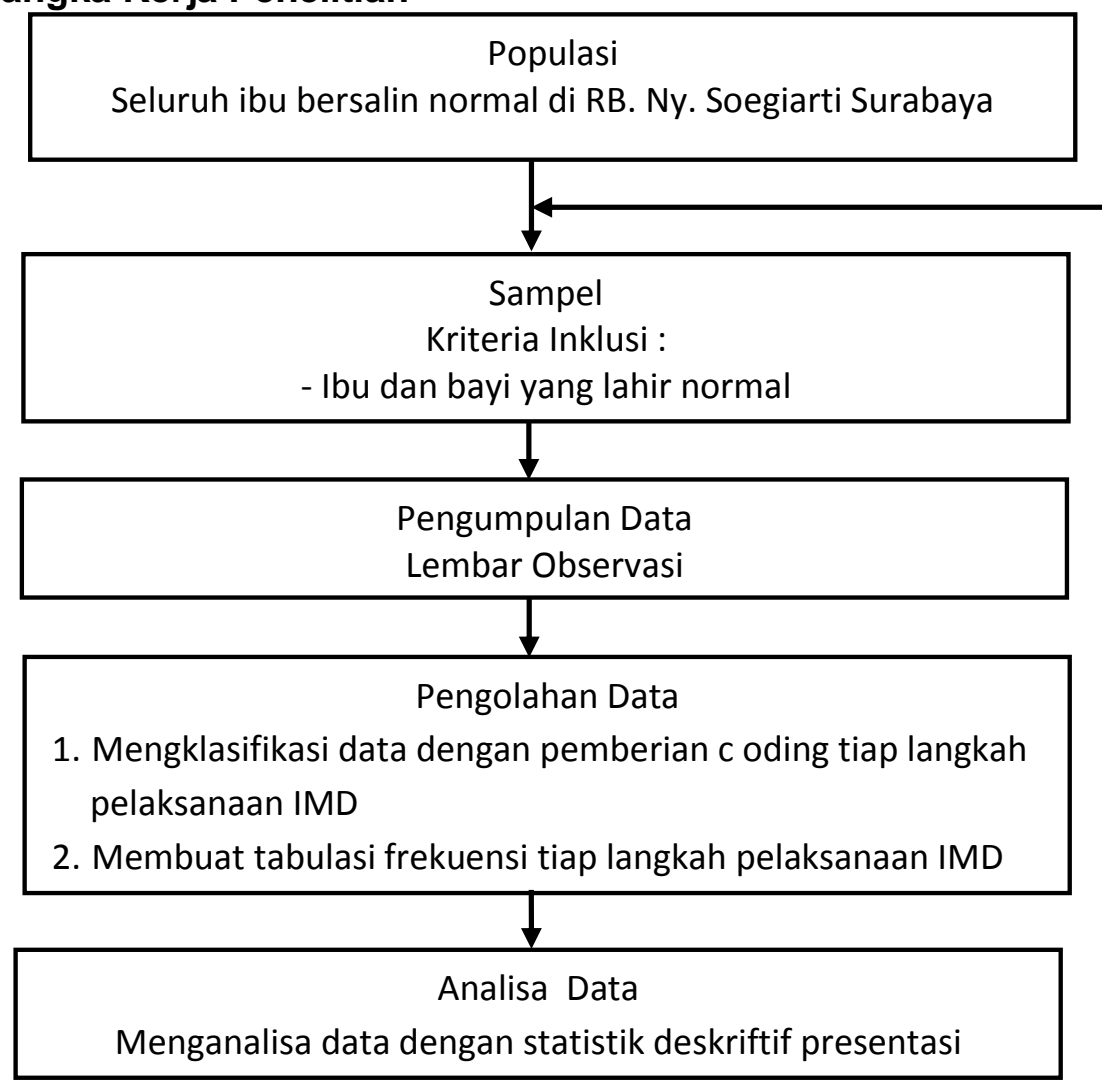

Gambar 4.1. Kerangka Kerja Penelitia Gambaran Pelaksanaan IMD Pada Ibu Bersalin Normal 
D. Populasi, Sampel, Besar Sampel dan Sampling

\section{Populasi Penelitian}

Populasi dalam penelitian ini adalah seluruh ibu bersalin normal yang melahirkan di RB. Ny. Soegiarti Surabaya, dengan rata-rata jumlah persalinan setiap bulan 15 persalinan.

2. Sampel Penelitian

Sampel dalam penelitian ini adalah sebagian populasi yang memenuhi kriteria inklusi yaitu ibu bersalin yang melahirkan bayi secara normal di RB Ny. Soegiarti Surabaya pada bulan Oktober - Desember 2013. Besar sampel sebanyak 30 orang.

3. Teknik Sampling.

Teknik sampling yang dipakai pada penelitian ini adalah purposive sampling. Adapun pengambilan dalam penelitian ini dengan cara mengambil responden yang datang di RB Ny. Soegiarti Surabaya sesuai urutan dan yang memenuhi kriteria inklusi sampai terpenuhinya jumlah responden yang ditentukan.

\section{A. Identifikasi Variabel}

Variabel pada penelitian ini adalah pelaksanaan inisiasi menyusu dini dengan sub variabel posisi bayi, upaya mencegah bayi kedinginan, bayi mencari puting susu ibu, dan lamanya bayi menyusu.

\section{B. Instrumen Penelitian}

Pada penelitian ini instrumen yang digunakan adalah kuesioner.

\section{H. Pengumpulan Data dan Analisa Data}

1. Pengumpulan Data

Teknik pengumpulan data dalam penelitian ini adalah dengan menggunakan data primer yang diperoleh langsung dari ibu bersalin yang melahirkan di RB $\mathrm{Ny}$. Soegiarti Surabaya. Pengumpulan data ini menggunakan kuesioner yang disodorkan pada ibu bersalin dalam waktu tidak kurang dari 24 jam setelah persalinan. Kuesioner berisi tentang pertanyaan mengenai langkah-langkah pelaksanaan IMD.

2. Analisa Data

Data yang diperoleh selanjutnya dilakukan pengolahan data sebagai berikut: 1) mengumpulkan data, 2) mengklasifikasi data dengan pemberian coding tiap pertanyaan langkah pelaksanan IMD, 3) membuat tabulasi frekuensi tiap pertanyaan langkah pelaksanaan IMD, 4) menganalisa data dengan statistik deskriftif presentasi dengan

rumus:

$$
\% \text { Setiap Sub Variabel }=\frac{\text { Jumlah absolut setiap sub variabel }}{\text { Jumlah Responden }} \times 100 \%
$$

\section{HASIL PENELITIAN}

Dalam bab ini diuraikan tentang hasil penelitian yang dilaksanakan di Rumah Bersalin Ny. Soegiarti Surabaya, pada bulan Oktober - Desember 2013 dengan responden 30 orang. Hasil penelitian dalam bab ini disajikan data umum dan data khusus dalam bentuk tabel.

\section{A. Data Umum}

Data umum berupa karakteristik ibu bersalin yang meliputi umur, pendidikan terakhir, pekerjaan, dan jumlah anak dapat dilihat pada tabel berikut ini:

\section{Umur Responden}

Tabel 5.1. Distribusi Responden Berdasarkan umur lbu Bersalin di RB Ny. Soegiarti Surabaya.

\begin{tabular}{llll}
\hline NO & $\begin{array}{l}\text { Umur } \\
\text { (Thn) }\end{array}$ & $\begin{array}{l}\text { Frsiekuen } \\
(\mathbf{f})\end{array}$ & $\begin{array}{l}\text { Persentase } \\
(\%)\end{array}$ \\
\hline 1 & $<20$ & 0 & 0 \\
2 & $20-35$ & 27 & 90 \\
3 & $>35$ & 3 & 10 \\
\hline Jumlah & $\mathbf{3 0}$ & $\mathbf{1 0 0}$ \\
\hline
\end{tabular}

Tabel 5.1 dapat dijelaskan bahwa dari 30 responden, kelompok umur terbanyak antara umur 20-35 tahun sebanyak 27 responden $(90 \%)$ 
2. Pendidikan

Tabel 5.2. Distribusi Responden Berdasarkan Pendidikan lbu Bersalin di RB Ny. Soegiarti Surabaya.

\begin{tabular}{llll}
\hline NO & Pendidikan & $\begin{array}{c}\text { Frsiekuen } \\
(\mathbf{f})\end{array}$ & $\begin{array}{c}\text { Persentase } \\
(\%)\end{array}$ \\
\hline 1 & SD & 2 & 7 \\
2 & SMP & 3 & 10 \\
3 & SMA & 18 & 60 \\
4 & Perguruan & 7 & 23 \\
& Tinggi & & \\
\hline \multicolumn{2}{l}{ Jumlah } & $\mathbf{3 0}$ & $\mathbf{1 0 0}$ \\
\hline
\end{tabular}

Tabel 5.2 dapat dijelaskan bahwa dari 30 responden, kelompok pendidikan terbanyak adalah SMA banyak 18 responden (60\%)

\section{Pekerjaan}

Tabel 5.3.Distribusi Responden Berdasarkan Pekerjaan Ibu Bersalin di RB Ny. Soegiarti Surabaya.

\begin{tabular}{llll}
\hline NO & Pekerjaan & $\begin{array}{l}\text { Frsiekuen } \\
(\mathbf{f})\end{array}$ & $\begin{array}{l}\text { Persentase } \\
(\%)\end{array}$ \\
\hline 1 & Swasta & 13 & 43 \\
2 & PNS & 1 & 3 \\
3 & Wiraswasta & 2 & 7 \\
4 & Tidak & 14 & 47 \\
& Bekerja & & \\
\hline Jumlah & $\mathbf{3 0}$ & $\mathbf{1 0 0}$ \\
\hline
\end{tabular}

Tabel 5.3 dapat dijelaskan bahwa dari 30 responden, kelompok pekerjaan terbanyak adalah tidak bekerja sebanyak. 14 responden $(47 \%)$

\section{Paritas}

Tabel 5.4. Distribusi Responden Berdasarkan Paritas lbu Bersalin di RB Ny. Soegiarti Surabaya.

\begin{tabular}{llll}
\hline NO & Paritas & $\begin{array}{c}\text { Frsiekuen } \\
\text { (f) }\end{array}$ & $\begin{array}{c}\text { Persentase } \\
\text { (\%) }\end{array}$ \\
\hline 1 & Primipara & 12 & 40 \\
2 & Multipara & 17 & 57 \\
3 & $\begin{array}{l}\text { Grandemult } \\
\text { ipara }\end{array}$ & 1 & 3 \\
& & $\mathbf{1 0 0}$ \\
\hline Jumlah & $\mathbf{3 0}$ &
\end{tabular}

Tabel 5.4 dapat dijelaskan bahwa dari 30 responden, kelompok paritas yang

paling tinggi adalah multipara sebanyak 17 responden (57\%)

\section{B. Data Khusus}

Pada data khusus ini akan diuraikan sesuai sesuai dengan tujuan penelitian yaitu pelaksanaan inisiasi menyusu dini pada ibu bersalin normal.

5.2.1. Pelaksanaan Inisiasi Menyusu Dini Pada Ibu Bersalin Normal

Tabel 5.5 Distribusi Frekuensi Pelaksanaan Inisiasi Menyusu Dini Pada lbu Bersalin Normal di RB. Ny. Soegiarti Surabaya.

\begin{tabular}{|l|l|l|l|l|l|r|r|}
\hline NO & KEGIATAN & \multicolumn{2}{|l|}{ YA } & \multicolumn{2}{|l|}{ TIDAK } & JUMLAH \\
\cline { 3 - 8 } & & N & $\%$ & N & $\%$ & N & $\%$ \\
\hline 1 & Bayi ditengkurapkan didada ibu & 30 & 100 & 0 & 0 & 30 & 100 \\
\hline 2 & $\begin{array}{l}\text { Kulit bayi melekat dengan kulit ibu } \\
\text { tanpa dialasi kain }\end{array}$ & 26 & 87 & 4 & 13 & 30 & 100 \\
\hline 3 & $\begin{array}{l}\text { Upaya mencegah bayi kedinginan } \\
\text { dengan kepala bayi dipakaikan } \\
\text { topi dan diselimuti ibu dan bayi }\end{array}$ & 20 & 67 & 10 & 33 & 30 & 100 \\
\hline 4 & $\begin{array}{l}\text { Bayi dibiarkan untuk mencari } \\
\text { sendiri puting susu ibunya dan } \\
\text { bayi tidak dipaksakan ke puting } \\
\text { susu ibu }\end{array}$ & 9 & 30 & 21 & 70.00 & 30 & 100 \\
\hline 5 & $\begin{array}{l}\text { Bayi tetap dibiarkan dalam posisi } \\
\text { kulit bayi melekat dengan kulit ibu } \\
\text { sampai proses menyusu pertama } \\
\text { selesai atau selama 1-2 jam }\end{array}$ & 47 & 16 & 53 & 30 & 100 \\
\hline
\end{tabular}

Tabel 5.5 dapat dijelaskan bahwa langkah-langkah pelaksanaan inisiasi menyusu dini yaitu bayi ditengkurapkan didada ibu sebanyak 30 responden (100\%), kulit bayi melekat dengan kulit ibu tanpa dialasi kain sebanyak 26 responden (87\%), Upaya mencegah bayi 
kedinginan dengan kepala bayi dipakaikan topi dan diselimuti ibu dan bayi sebanyak 20 responden (67\%), bayi dibiarkan untuk mencari sendiri puting susu ibunya dan bayi tidak dipaksakan ke puting susu 9 responden (30\%), bayi tetap dibiarkan dalam posisi kulitnya bersentuhan dengan kulit ibu sampai proses menyusu pertama selesai atau selama 1-2 jam 14 responden (47\%).

\section{PEMBAHASAN}

Pada bab ini akan dibahas mengenai pelaksanaan inisiasi menyusu dini (IMD) pada ibu bersalin normal di RB. Ny. Soegiarti Surabaya antara lain data hasil penelitian dikaitkan dengan teori.

\section{A. Posisi Bayi Dalam Pelaksanaan IMD}

Menurut hasil penelitian yang diperoleh pada tabel 5.5 adalah bahwa langkah-langkah pelaksanaan inisiasi menyusu dini yaitu langkah pertama bayi ditengkurapkan di dada atau perut ibu menunjukkan hasil bahwa dari 30 responden (100\%) semuanya dilakukan IMD oleh Bidan dengan tepat. Hal ini dapat ditunjukkan bahwa bayi baru lahir segera ditengkurapkan di dada atau perut ibu untuk dilakukan IMD.

Menurut Roesli Utami (2012), bayi baru lahir segera dikeringkan dan diletakkan di perut ibu dengan kontak kulit bayi ke kulit ibu dan tidak dipisahkan dari ibunya setidaknya satu jam. Dalam 30 menit pertama bayi dalam tahap istirahat yang siaga dengan wajah menghadap ke payudara kanan. Kemudian bayi mulai menjilat-jilat dada ibu. Kaki bayi mulai menekan perut ibu untuk mendekati payudara. Kemudian kepala bayi menengok ke arah payudara kiri sampai menemukan putting susu payudara kiri.

Pada langkah yang pertama ini pelaksanaan IMD dapat berjalan dengan tepat. Dalam langkah pertama ini $100 \%$ benar dilakukan oleh Bidan yang sudah mendapatkan pelatihan sebelumnya sehingga pelaksanaannya dapat $100 \%$ benar. Walaupun langkah pertama dilakukan dengan tepat tidak dapat mewakili dari semua langkahlangkah dalam pelaksanaan IMD.

\section{B. Kontak Kulit Ibu Dan Bayi Dalam Pelaksanaan IMD}

Langkah kedua pelaksanaan IMD yaitu kulit bayi melekat dengan kulit ibu tanpa dialasi kain, dari 30 responden sebanyak 26 responden (86.67\%) telah dilakukan dengan tepat. Sedangkan terhadap 4 responden $(13.33 \%)$ bidan tidak melakukan langkah ini dengan tepat.

Menurut penelitian Dr. Niels Bergman dari Afrika Selatan dalam buku Roesli Utami (2012), kulit dada ibu yang melahirkan satu derajat lebih panas dari ibu yang tidak melahirkan. Jika bayinya kedinginan, suhu kulit ibu otomatis naik dua derajat untuk menghangatkan bayi. Jika bayi kepanasan, suhu kulit ibu otomatis turun satu derajat untuk mendinginkan bayinya. Kulit ibu bersifat termoregulator atau thermal synchrony bagi suhu bayi. Dengan demikian jika langkah ini dilakukan dengan tepat maka akan mencegah bayi hipotermi. Hal ini sesuai dengan keuntungan IMD yaitu mencegah kehilangan panas pada bayi.

Dalam langkah ini terdapat 4 responden yang pelaksanaannya kurang tepat. Hal ini dikarenakan bayi dipakaikan bedong saat pelaksanaan IMD. Ibu takut bayinya kedinginan sehingga dalam keadaan dibedong bayi diletakkan di dada ibu. Selain itu ibu masih memakai baju sehingga kulit bayi dan kulit ibu tidak bersentuhan secara langsung. Ibu tidak mau membuka bajunya dikarenakan malu dan belum mengetahui informasi tentang IMD sebelumnya. Dalam pelaksanaan IMD kontak kulit bayi dengan kulit ibu sangat dibutuhkan karena dapat terjadi ikatan kasih sayang antara bayi dan ibu, serta bayi dan ibu akan merasa lebih tenang.

\section{Upaya Mencegah Bayi Kedinginan Dalam Pelaksanaan IMD}

Langkah ketiga pelaksanaan IMD yaitu upaya mencegah bayi kedinginan dengan kepala bayi dapat dipakaikan topi dan diselimuti pada daerah 
punggung bayi. Dari 30 responden sebanyak 20 responden (66.67\%) pelaksanaannya sudah tepat. Sedangkan 10 responden (33.33\%) pelaksanaannya kurang tepat.

Menurut Roesli Utami (2012), tanpa dibedong bayi langsung ditengkurapkan di dada atau perut ibu dengan kontak kulit bayi dan kulit ibu. Kemudian bayi diselimuti. Bayi diberi topi untuk mengurangi pengeluaran panas dari kepalanya.

Pelaksanaan IMD pada langkah ketiga ini sebagian besar sudah tepat. lbu bersalin dapat kooperatif dengan petugas kesehatan saat dilakukan IMD. Namun ada pelaksanaannya yang kurang tepat dikarenakan bayi tidak dipakaikan topi, dan bayi tidak diselimuti. Bayi tidak dipakaikan topi karena pada saat persalinan ibu tidak menyiapkan topi sebelumnya, dan tidak disediakan topi bayi di tempat bersalin. Sehingga ketersediaan sarana dan prasarana atau alat-alat untuk menunjang pelaksanaan IMD tersebut kurang. Kurangnya sarana dan prasarana tersebut dapat menurunkan kualitas pelaksanaan IMD, dan kepala bayi merupakan bagian yang sangat besar yang bisa dengan cepat menyebabkan hipotermi. Pelaksanaan IMD menjadi kurang maksimal jika salah satu langkah tidak dilaksanakan dengan tepat.

\section{Bayi Mencari Putting Susu Dalam Pelaksanaan IMD}

Langkah keempat pelaksanaan IMD yaitu bayi dibiarkan untuk mencari sendiri puting susu ibunya dan bayi tidak dipaksakan ke puting susu. Dari 30 responden sebanyak 21 responden (70\%) pelaksanaannya kurang tepat. Sedangkan sebanyak 9 responden $(30 \%)$ pelaksanaannya sudah tepat.

Menurut Roesli Utami (2012), pada langkah ini proses alami bayi tanpa dipaksakan ke puting susu ibu. Otak bayi harus berkembang sehingga bayi harus mencari-cari payudara ibu sendiri.

Menurut Riksani Ria (2012), saat bayi berhasil menemukan puting susu ibu dan menyusu untuk pertama kalinya, saat itulah bayi mendapatkan kolostrum. Kolostrum sudah diketahui mempunyai banyak manfaat, salah satunya kaya akan zat kekebalan tubuh yang dapat melindungi tubuh bayi dari berbagai jenis infeksi.

Langkah keempat ini sebagian besar pelaksanaannya kurang tepat dikarenakan bayi lebih banyak dibantu untuk menemukan puting susu ibu dan bayi dipaksakan ke puting susu ibu. Hal ini menjadikan pelaksanaan IMD pada langkah ini kurang maksimal. Bayi harus menyusu sendiri karena isapan bayi pada puting ibu akan merangsang pengeluaran hormon prolaktin (yang merangsang produksi ASI) dan hormon oksitosin (yang merangsang pengeluaran ASI). Hal ini bermanfaat agar kolostrum lebih cepat keluar, sehingga bayi mendapatkan kolostrum. Saat bayi berhasil menyusu dini ini akan mempengaruhi keberhasilannya dalam menyusu secara eksklusif berikutnya.

\section{E. Lama Bayi Menyusu Dalam Pelaksanaan IMD}

Langkah kelima pelaksanaan IMD yaitu bayi tetap dibiarkan dalam posisi kulitnya bersentuhan dengan kulit ibu sampai proses menyusu pertama selesai atau selama 1-2 jam. Dari 30 responden sebanyak 16 responden $(53.33 \%)$ pelaksanaannya tidak sampai 2 jam, melainkan hanya 30 menit bahkan ada yang hanya 10 menit. Sedangkan sebanyak 14 responden (46.67\%) pelaksanaannya sudah tepat. Karena IMD dilakukan sampai proses menyusu pertama bayi selesai atau selama 1-2 jam.

Menurut Roesli Utami (2012), "Bonding" (ikatan kasih sayang) antara ibu dan bayi akan lebih baik karena pada 1-2 jam pertama, bayi dalam keadaan siaga. Setelah itu, biasanya bayi tidur dalam waktu yang lama.

Pada langkah ini pelaksanaan IMD sebagian besar kurang tepat. Hal ini dikarenakan proses menyusu bayi tidak sampai proses menyusu pertama selesai. Proses IMD dilaksanakan paling lama 30 menit dengan alasan ibu yang bersalin tidak mau terlalu 
lama dilakukan IMD dan Bidan kurang sabar dalam menunggu proses IMD. Tetapi terdapat pelaksanaan yang sudah tepat karena ibu bersalin dapat kooperatif dengan petugas kesehatan dan Bidan dapat lebih sabar dalam pelaksanaan IMD tersebut.

Pelaksanaan IMD di RB Ny. Soegiarti Surabaya, dari 30 responden pelaksanaannya kurang maksimal. Sebenarnya Bidan sudah melaksanakan IMD pada semua ibu bersalin normal, namun pelaksanaannya kurang maksimal hal ini terbukti pada pelaksanaan IMD masih ada langkah yang dilakukan dengan tidak tepat. Seharusnya bidan melaksanakan langkah-langkah IMD dengan tepat karena pelaksanaan IMD itu sendiri tertuang dalam APN yang merupakan standar atau sebagai acuan bagi bidan dalam melakukan pertolongan persalinan sehingga semua Bidan wajib melakukan standar IMD tersebut.

Petugas kesehatan dalam melakukan IMD seharusnya sesuai dengan protap dan tatalaksana IMD. Petugas kesehatan khususnya bidan sangat berpengaruh terhadap terlaksana atau tidaknya inisiasi menyusu dini. Petugas kesehatan dianjurkan untuk menyampaikan informasi IMD kepada orang tua dan keluarga sebelum melakukan IMD agar tercipta suasana yang tenang, nyaman, dan penuh kesabaran untuk memberi kesempatan bayi merangkak mencari payudara ibu. Bahkan IMD sudah harus diberikan informasinya pada saat ibu memeriksakan kehamilannya.

Pelaksanaan IMD harus tetap ditingkatkan. Inisiasi menyusu dini dapat meningkatkan keberhasilan menyusu eksklusif dan lama menyusu sampai dua tahun. Dengan demikian, dapat menurunkan kematian anak secara menyeluruh.

\section{Kesimpulan}

Sesuai hasil penelitian dan pembahasan dapat disimpulkan bahwa :

1. Langkah pertama pelaksanaan IMD yaitu bayi ditengkurapkan di dada atau perut ibu menunjukkan hasil bahwa sebanyak 30 ibu bersalin (100\%) dilakukan IMD oleh Bidan dengan tepat.

2. Langkah kedua pelaksanaan IMD yaitu kulit bayi melekat dengan kulit ibu tanpa dialasi kain sebanyak 26 ibu bersalin (87\%) telah dilakukan dengan tepat.

3. Langkah ketiga pelaksanaan IMD yaitu upaya mencegah bayi kedinginan dengan kepala bayi dapat dipakaikan topi dan diselimuti pada daerah punggung bayi sebanyak 20 ibu bersalin $(67 \%)$ pelaksanaannya sudah tepat.

4. Langkah keempat pelaksanaan IMD yaitu bayi dibiarkan untuk mencari sendiri puting susu ibunya dan bayi tidak dipaksakan ke puting susu sebanyak 9 ibu bersalin (30\%) pelaksanaannya sudah tepat.

5. Langkah kelima pelaksanaan IMD yaitu bayi tetap dibiarkan dalam posisi kulitnya bersentuhan dengan kulit ibu sampai proses menyusu pertama selesai atau selama 1-2 jam sebanyak 14 ibu bersalin (47\%) pelaksanaannya sudah tepat.

6. Pelaksanaan IMD di RB. Ny. Soegiarti Surabaya, pelaksanaannya kurang maksimal karena masih ada langkah yang pelaksanaannya kurang tepat.

\section{Saran}

Dari hasil penelitian dapat disarankan :

1. Bagi Tempat Penelitian

Semua petugas pelayanan kebidanan disarankan untuk mengikuti pelatihanpelatihan tentang IMD karena dengan pelatihan akan meningkatkan keterampilan dalam pelaksanaan IMD.

2. Bagi Peneliti Selanjutnya

Demi kepentingan ilmiah, maka di harapkan ada kelanjutan dari penelitian ini, sehingga menjadi lebih baik dan secara otomatis juga memberikan solusi yang terbaru dengan masalah yang ada, yaitu meneliti faktor-faktor yang mempengaruhi pelaksanaan IMD. 


\section{DAFTAR PUSTAKA}

Administrator.(2010). Badan Penelitian Dan Pengembangan Kesehatan. Selasa Maret 2013. http://www.riskesdas.litbang.depkes.g o.id.

Arikunto, Suharsimi. (2010). Prosedur Penelitian Suatu Pendekatan Praktik.Jakarta : Rineka Cipta.

Dwilistyowati, Lita. (2012). Manfaat Dan Penghambat Inisiasi Menyusu Dini. Senin Februari 2013. http://alwaysnutritionist.com

Kristiyansari, Weni. (2009). ASI, Menyusui \& SADARI.Yogjakarta : Nuha Medika.

Manuaba, Ida Bagus. (2010). IImu Kebidanan Penyakit Kandungan dan Keluarga Berencana Untuk Pendidikan Bidan. Jakarta : EGC.

Marmi.(2012). Intranatal Care Asuhan Kebidanan Pada Persalinan.Yogyakarta : Pustaka Pelajar.

Notoatmodjo, Soekidjo. (2003). Pendidikan dan Perilaku Kesehatan.Jakarta : Rineka Cipta

Notoatmodjo, Soekidjo. (2010). Metodologi Penelitian Kesehatan.Jakarta: Rineka Cipta.

Proverawati, Eni Rahmawati. (2010). Kapita Selekta ASI \& Menyusui.Yogjakarta : Nuha Medika.

Pusat Komunikasi Publik. (2012). Pedoman Pekan ASI Sedunia 2012.Selasa Maret 2013. http://www.slideshare.net.

Riksani, Ria. (2012). Keajaiban ASI.Jakarta : Dunia Sehat.

Roesli, Utami. (2012). Panduan Inisiasi Menyusu Dini Plus ASI Eksklusif.Jakarta : Pustaka Bunda.
Sejatiningsih, Sri. ( 2013). Program Inisiasi Menyusu Dini dalam rangka Menurunkan Angka Kematian Neonatal. Tesis.Bandung :Universitas Padjadjaran.

Soewadji, Jusuf. (2012). Pengantar Metodologi Penelitian.Jakarta : Mitra Wacana Media. 